\title{
Rumen fermentation and nutrient flow to the omasum in Holstein cows fed extruded canola seeds treated with or without lignosulfonate ${ }^{1}$
}

\author{
Wallacy Barbacena Rosa dos Santos ${ }^{2}$, Geraldo Tadeu dos Santos ${ }^{3}$, Carolina Antunes Neves ${ }^{3}$ \\ Francilaine Eloise De Marchi ${ }^{3}$, Daniele Cristina da Silva-Kazama ${ }^{4}$, Luís Carlos Vinhas Ítavo ${ }^{5}$, \\ Julio Cesar Damasceno ${ }^{3}$, Hélène Veronique Petit ${ }^{6}$
}

\author{
1 Project financed by Fundação Araucária, and MCT-CNPq, PRONEX, 2007. \\ 2 Departamento de Produção Animal, IFAM, Maués, AM, Brasil. \\ 3 Departamento de Zootecnia, UEM, Maringá, PR, Brasil. \\ ${ }^{4}$ Departamento de Zootecnia e Desenvolvimento Rural, UFSC, Florianópolis, SC, Brasil. \\ ${ }^{5}$ Departamento de Zootecnia, UCDB, Campo Grande, MS, Brasil. \\ ${ }^{6}$ Dairy and Swine Research and Development Centre, Agriculture and Agri-Food Canada, QC, Canada.
}

\begin{abstract}
Four multiparous Holstein cows averaging $548 \mathrm{~kg}$ of body weight and $74 \mathrm{~d}$ in lactation were used in a Latin square design with four 21-d experimental periods to determine effects of feeding extruded versus non-extruded canola seed, with or without $50 \mathrm{~g} / \mathrm{kg}$ lignosulfonate on rumen fermentation, nutrient flow to the omasum, and degradability of dry matter (DM) and $\mathrm{N}$ of each diet. The DM effective degradability increased with extrusion and lignosulfonate treatment had no effect. The effective degradability of $\mathrm{N}$ was similar between diets. Lignosulfonate treatment of extruded versus non-extruded canola seeds decreased ruminal and total tract apparent digestibility of organic matter. The lowest apparent ruminal and highest intestinal digestibilities of protein, expressed as a percentage of $\mathrm{N}$ intake were observed for cows fed extruded canola seeds without lignosulfonate. Lignosulfonate treatment and extrusion had no effect on $\mathrm{pH}$ and concentrations of ammonia $\mathrm{N}$ and volatile fatty acids in the rumen. Results suggest that extruded canola seed untreated with formaldehyde may stimulate efficiency of microbial protein synthesis and is an effective means of increasing the availability of protein in the small intestine without affecting the total tract apparent digestibility of protein.
\end{abstract}

Key Words: chemical treatment, digestion, heat treatment, oilseed

\section{Introduction}

Heat treatment is commonly used to protect oilseeds from ruminal degradation (Mustafa et al., 2002; AbuGhazaleh et al., 2002a,b). Kennelly (1996) suggested that the application of heat to highly fat products such as oilseeds can denature the protein matrix surrounding the fat droplets, thus preventing the access of ruminal bacteria to fatty acids, protecting the dietary fat from ruminal biohydrogenation. Extrusion is a method to heat-processed oilseeds that has the potential of reducing ruminal crude protein (CP) degradability (Petit et al., 1999) and N solubility (Chouinard et al., 1997a) as shown for full fat soybeans. Moreover, extrusion results in a slow-release of linoleic acid from full-fat soybeans in the rumen (Peterson et al., 2002), with little effect on ruminal fermentation (Scott et al., 1991). However, previous results have shown that extrusion of canola seeds has no effect on total tract apparent digestibility, but it decreases milk fat concentration (Neves et al., 2009), which may result in a potential negative effect of extruding canola seeds on ruminal digestion.
Lignosulfonate, which is a by-product of the wood industry, decreases ruminal degradability of $\mathrm{CP}$ and increases the rumen undegradable $\mathrm{CP}$ concentration of full fat soybeans by up to $173 \%$ (Petit et al., 1999). However, there is little information on the effect of lignosulfonate treatment on ruminal degradability of ground canola seeds. Results from a previous experiment (Neves et al., 2009) showed that extrusion of canola seeds increased milk fat concentration of trans11-18:1 to a lower extent with, than without, lignosulfonate treatment (113 versus $150 \%$ ) and that concentrations of cis 9 , trans 11 conjugated linoleic acid and polyunsaturated fatty acids were similar between treatments. However, the concentration of trans11-18:1 increased with extrusion of full fat soybeans but not with lignosulfonate treatment and concentrations of cis 9 , trans 11 conjugated linoleic acid and polyunsaturated fatty acids tended $(\mathrm{P}=0.08$ and $\mathrm{P}=0.06$, respectively) to increase with lignosulfonate treatment of full fat soybeans (Neves et al., 2007). Taken together, these results suggest that it is possible to modify the milk fatty acid composition by feeding extruded oilseeds, but the effect of lignosulfonate 
treatment on the milk fatty acid profile seems to differ depending on the type of oilseed treated. Enhanced comprehension of ruminal metabolism and nutrient utilization of extruded oilseeds treated with lignosulfonate will help to manipulate milk fatty acid profile. Although research has been conducted with supplementing canola to alter ruminal fermentation and $\mathrm{N}$ metabolism in the gastrointestinal tract, none could be found on effects of treating ground canola seeds with both extrusion and lignosulfonate.

The objectives of this experiment were to determine the effects of extrusion and lignosulfonate treatment of ground canola seeds on ruminal fermentation, ruminal degradability, and nutrient flow to the omasum in earlylactating dairy cows.

\section{Material and Methods}

Four rumen-fistulated multiparous Holstein cows averaging $548.1 \pm 66.9 \mathrm{~kg}$ of body weight and $74 \pm 12$ days in lactation were assigned to a $4 \times 4$ Latin square design to determine the effects of extrusion and lignosulfonate treatment of canola seed on rumen fermentation, digestibility in the rumen, the intestine and the total tract, and degradability of dry matter (DM) and $\mathrm{N}$ of each diet. Each experimental period consisted of $14 \mathrm{~d}$ of adaptation to the diets and $7 \mathrm{~d}$ for sample collection. Cows were housed in tie stalls and fed individually ( 8 a.m. and 4 p.m.). Cows were weighed on the first and last days of each experiment period. A full description of the four diets was given by Neves et al. (2009). Briefly, the four total mixed diets (Table 1) consisted of supplements based on non-extruded canola seeds, extruded canola seeds, non-extruded canola seeds treated with $50 \mathrm{~g} / \mathrm{kg}$ DM lignosulfonate or extruded canola seeds treated with $50 \mathrm{~g} / \mathrm{kg}$ DM lignosulfonate.

Feed intake was recorded daily and adjusted for $100 \mathrm{~g} / \mathrm{kg}$ orts as fed. Samples of each diet were collected daily from day 15 to 20 , frozen, and pooled on a period basis. Composite samples were mixed thoroughly and subsampled for chemical analyses. Fecal grab samples (100 g) obtained via rectal palpation and spot samples (ca. $500 \mathrm{~mL}$ ) of the omasal digesta leaving the rumen were collected and accumulated for four consecutive days at 8,12, 16 and 20 hours of each experimental period for days $16,17,18$, and 19 , respectively. The omasal sampling technique was similar to that of Huhtanen et al. (1997). Samples of feces and omasal digesta were kept at $-20^{\circ} \mathrm{C}$ for further analyses. Indigestible neutral detergent fiber (iNDF) was the marker to measure omasal flow (Huhtanen et al., 1994). On day 21, rumen fluid samples were collected at $0,2,4,6$, and 8 hours from different sites within the rumen to obtain a total of around $200 \mathrm{~mL}$. Ruminal contents were filtered with cheesecloth and the ruminal fluid $\mathrm{pH}$ was measured immediately (HI $931000 \mathrm{pH}$ meter; Hanna Instruments, Ronchi di Villafranca, PD, Italy). Samples were acidified to $\mathrm{pH} 2$ with $1 \mathrm{ml}$ of $20 \% \mathrm{H}_{2} \mathrm{SO}_{4}$ and frozen at $-20{ }^{\circ} \mathrm{C}$ for determination of volatile fatty acids (VFA) and ammonia $\mathrm{N}$ concentrations. Another sample of ruminal

Table 1 - Ingredient and chemical composition of total mixed diets of Holstein cows fed non-extruded untreated canola seeds (NEC), extruded untreated canola seeds (EXC), non-extruded canola seeds treated with $50 \mathrm{~g} / \mathrm{kg}$ DM of lignosulfonate (NEL) or extruded canola seeds treated with $50 \mathrm{~g} / \mathrm{kg}$ DM of lignosulfonate (EXL)

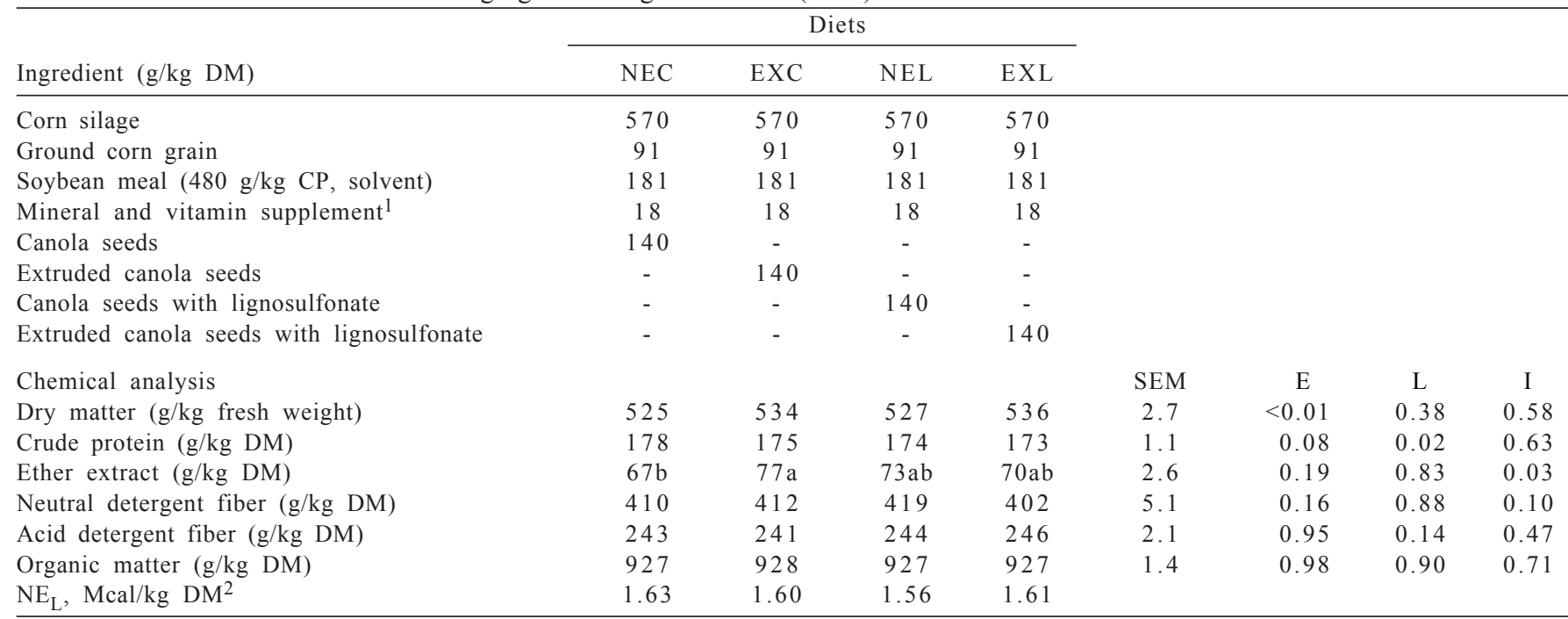

a,b Means within rows and lignosulfonate treatment with different letters differ $(\mathrm{P}<0.05)$.

$\mathrm{SEM}=$ standard error of the mean; $\mathrm{NE}_{\mathrm{L}}=$ net energy of lactation; $\mathrm{E}=$ extrusion, $\mathrm{L}=$ lignosulfonate; $\mathrm{I}=$ interaction.

${ }^{1}$ Contained: Ca - 270 g/kg; P - 80 g/kg; Mg - 20 g/kg; S - 20 g/kg; Fe - 2200 mg/kg; Zn - 2800 mg/kg; Cu - $800 \mathrm{mg} / \mathrm{kg} ; \mathrm{F}-801 \mathrm{mg} / \mathrm{kg}$ of F; I - 60 mg/kg; Co - 50 mg/kg; $\mathrm{Se}-40 \mathrm{mg} / \mathrm{kg}$; vitamin A - 216,000 IU/kg; vitamin $\mathrm{D}_{3}-67,600 \mathrm{UI} / \mathrm{kg}$; vitamin $\mathrm{E}-500 \mathrm{IU} / \mathrm{kg}$.

2 Calculated using published values of feed ingredients (NRC, 2001). 
contents (ca. $3 \mathrm{~kg}$ ) was collected from each cow from different sites within the rumen before the 08:00 $\mathrm{h}$ feeding and processed according to the procedure of Cecava et al. (1990) to determine microbial protein synthesis as described by Ushida et al. (1985).

Ruminal in situ incubations were carried out using three rumen fistulated multiparous cows fed the non-extruded untreated canola seeds. The diet was fed ad libitum for two weeks before the incubation trial. Samples of each of the four canola treatments were milled through a $2-\mathrm{mm}$ screen and subsamples $(6 \mathrm{~g})$ were then placed in nitrogen-free polyester bags $(10 \times 20 \mathrm{~cm})$ with a pore size of $50 \pm 15 \mu \mathrm{m}$ (R1020 Ankom products; Ankom, Fairport, NY, USA). Samples of each canola treatment were incubated in the rumen of each cow for $72,48,36,24,12,8,6,4,2$, and $0 \mathrm{~h}$. The bags were inserted in reverse order of incubation period, so that they could all be removed at the same time (NRC, 2001). All bags were incubated in duplicate for each time point of incubation except for $72 \mathrm{~h}$, when bags were incubated in triplicate to have enough residue for chemical analyses. All bags were attached to a stainless-steel weight of $540 \mathrm{~g}$, and placed in the ventral sac of the rumen. Once the bags were removed from the rumen, they were immersed in 20-L buckets containing cold water, then washed in an automatic washing machine (40 min, 4 cycles; $5 \times 1$-min wash, 2-min spin) until the rinse water was clear. The bags (with residues) were then frozen.

Degradation of dry matter (DM) and N were calculated using the following first-order model with a lag of $t_{0}$ based on the model of McDonald (1981):

$\mathrm{p}=\mathrm{a}$ if $t<$ or $=$ to,

$\mathrm{p}=\mathrm{a}+\mathrm{b}\left[1-\mathrm{e}^{\left(-\mathrm{c}\left(\mathrm{t}-\mathrm{t}_{0}\right)\right)}\right]$ if $t>t o$,

where $p=$ percentage disappearance at time $t, a=$ the intercept representing the portion of DM or $\mathrm{N}$ solubilized at time $0, b=$ the fraction of $\mathrm{DM}$ or $\mathrm{N}$ that is potentially degradable in the rumen, $c=$ the constant rate of disappearance of fraction $b$, and $t=$ time on incubation. The nonlinear parameters $a, b, c$, and $t_{0}$ were estimated by an iterative least squares procedure of the software SAS (Statistical Analyses System, version 5.0), and best-fit values were chosen with the Secant method using the convergence criterion $\left(10^{-8}\right)$ of SAS (Statistical Analyses System, version 5.0).

Values of effective degradability of DM (EDDM) and total N (EDTN) were calculated using the equation of Dhanoa et al. (1999) stated in terms of $a, b, c, t_{0}$, and $k$ (the rumen outflow rate at $\left.8 \% \mathrm{~h}^{-1}\right)$.

$E D M M$ or $E D T N=a+b c\left(\mathrm{e}^{(-\mathrm{k} . \mathrm{t})}\right) /(\mathrm{c}+\mathrm{k})$

Dry matter of the diets was determined in a forcedventilation oven according to the procedure 934.01 (AOAC, 1990). Total mixed diets were ground to pass through $1-\mathrm{mm}$ screen Wiley mill before analyses of N, ether extract (EE), acid detergent fiber (ADF), and neutral detergent fiber (NDF). Total N determination used a Tecnal TE-036/1 (Piracicaba, São Paulo, Brazil) following procedure 990.03 of AOAC (1990). Concentrations of NDF and ADF, including those of residual ash were measured according to the nonsequential procedures of Van Soest et al. (1991) with the use of amylase but without sodium sulfite in the neutral detergent solution. Ether extraction in diets was conducted with Tecnal TE-044/1 (Piracicaba São Paulo, Brazil) according to the method No. 7.060 of AOAC (1990). Indigestible NDF was used as an internal marker to estimate apparent nutrient digestibility and fecal output (Cochran et al., 1986; Dann et al., 2007). Preparation of feed, orts and fecal residues from in situ incubation followed by iNDF extraction was similar to the technique described by Ellis et al. (1984) for preparation of indigestible NDF (i.e., NDF remaining after $144 \mathrm{~h}$ of in situ incubation). Coefficients of apparent digestion of dietary components were determined by comparing dietary indigestible NDF concentration (corrected for that in orts) with fecal or omasal digesta indigestible NDF concentration as outlined by Cochran et al. (1986). Apparent digestibility in the small intestine was calculated as the difference between 100 and apparent digestibility in the rumen. Isolation of rumen bacteria was carried out following the procedure of Cecava et al. (1990).

All results were analyzed as a $4 \times 4$ Latin square design balanced for residual effect using the MIXED procedure of SAS (Statistical Analyses System, version 8.02) and with a $2 \times 2$ factorial arrangement of treatments. Data on in sacco degradability, intake, omasal flow, ruminal, intestinal and total tract apparent digestibility, and ruminal fermentation parameters were analyzed using the following general model:

$\mathrm{Y}_{\mathrm{ijk}}=\mu+\mathrm{C}_{\mathrm{i}}+\mathrm{P}_{\mathrm{j}}+\mathrm{T}_{\mathrm{k}}+\mathrm{e}_{\mathrm{ijk}}$ where: $Y_{i j k}=$ the dependent variable, $\mu$ = overall mean, $\mathrm{C}_{\mathrm{i}}=$ random effect of cow ( $\mathrm{i}=1$ to 4$), \mathrm{P}_{\mathrm{j}}=$ fixed effect of period $(\mathrm{k}=1$ to 4$), \mathrm{T}_{\mathrm{k}}=$ fixed effect of treatment $(\mathrm{k}=$ non-extruded untreated canola seeds, extruded untreated canola seeds, non-extruded canola seeds treated with $50 \mathrm{~g} / \mathrm{kg}$ DM of lignosulfonate and extruded canola seeds treated with $50 \mathrm{~g} / \mathrm{kg}$ DM of lignosulfonate), and $\mathrm{e}_{\mathrm{ijk}}=$ random residual error. Data on ruminal $\mathrm{pH}$, ammonia concentration and VFAs were analyzed as repeated measurements. The compound symmetry was used as the covariance structure. Treatments were compared to provide factorial contrasts: 1) non-extruded versus extruded canola, 2) with versus without lignosulfonate, and 3) the interaction between extrusion and lignosulfonate treatment. Significance was declared at $\mathrm{P}<0.05$ and a trend was accepted at $\mathrm{P} \leq 0.10$, unless otherwise stated. 


\section{Results and Discussion}

There was a trend $(\mathrm{P}=0.09)$ for an interaction between extrusion and lignosulfonate for the rapidly $(a)$ degradable fraction of DM; extruding canola seeds with lignosulfonate increased the rapidly degradable fraction of DM and there was no effect of extrusion in the absence of lignosulfonate (Table 2). Adding lignosulfonate to canola seeds had no effect on the slowly $(b)$ degradable fraction and the rate of degradation of DM. On the other hand, extrusion of canola seeds decreased the slowly $(b)$ degradable fraction of DM with no effect on the rate of degradation.

There was a significant interaction between extrusion and lignosulfonate for the rapidly $(a)$ degradable fraction of $\mathrm{N}$ and there was a trend $(\mathrm{P}=0.08)$ for the slowly (b) degradable fraction of $\mathrm{N}$. The lowest $(a)$ and highest $(b)$ values of $\mathrm{N}$ were obtained for extruded canola seeds treated with lignosulfonate. The rate of $\mathrm{N}$ degradation was similar between diets.

The fact that extrusion increased the percentage of DM solubilized at initiation of ruminal incubation and decreased the percentage of DM potentially degradable in the rumen is in agreement with results previously reported by Petit et al. (1997) for canola seeds. The percentage of DM solubilized at initiation of ruminal incubation was increased with extrusion in the presence of lignosulfonate while the percentage of $\mathrm{CP}$ solubilized at initiation of ruminal incubation was decreased. These results may suggest that the higher fraction of DM solubilized at initiation of ruminal incubation was not due to higher solubilization of the protein fraction but to a higher release of the lipid fraction. Processes such as extrusion have been shown to increase the release of oil from soybeans (Mohamed et al., 1988). Moreover, Chouinard et al. (1997b) reported a greater accumulation of trans intermediates isomers in milk fat of cows fed extruded compared with micronized soybeans and roasted soybeans, which may result from greater release of fat in the rumen that led to lipolysis and biohydrogenation of fatty acids by rumen microorganisms (Griinari \& Bauman, 1999).

Extrusion has been used to protect the protein of leguminous grains, such as peas, lupins and soybeans (Poncet \& Rémond, 2002) from ruminal degradation, but the effect on oilseeds rich in lipids has seldom been observed. Ferlay et al. (1992) found no effect of extrusion at $140^{\circ} \mathrm{C}$ on protein degradability of rapeseeds. Moreover, Deacon et al. (1988) found that extrusion increased the in situ soluble fraction of protein from canola seed although there were no differences in ruminal DM and $\mathrm{N}$ degradabilities between non-extruded versus extruded canola seed. Several researchers have reported that extrusion is less effective than other heat treatments such as roasting in protecting oilseeds from ruminal degradation (Pena et al., 1986; Reddy et al., 1994).

Lignosulfonate, which is a by-product of the wood industry, decreased the percentage of $\mathrm{N}$ solubilized at initiation of ruminal incubation of extruded versus nonextruded canola seeds. Previous results have shown that lignosulfonate decreases ruminal degradability and increases the rumen undegradable $\mathrm{CP}$ concentration of full fat soybeans (Petit et al., 1999). Moreover, according to Windschitl \& Stern (1988), the effective ruminal CP degradability of soybean meal treated with $50 \mathrm{~g} / \mathrm{kg} \mathrm{DM}$ lignosulfonate and heated at $90-95{ }^{\circ} \mathrm{C}$ for 45 min was significantly decreased when compared with untreated soybean meal. Similarly, treatment of canola screenings with $50 \mathrm{~g} / \mathrm{kg}$ DM lignosulfonate and heat at $100^{\circ} \mathrm{C}$ for 60 min (von Keyserlingk et al., 2000) and of canola meal with

Table 2 - In sacco degradability of total mixed diets of Holstein cows fed non-extruded untreated canola seeds (NEC), extruded untreated canola seeds (EXC), non-extruded canola seeds treated with $50 \mathrm{~g} / \mathrm{kg} \mathrm{DM}$ of lignosulfonate (NEL) or extruded canola seeds treated with $50 \mathrm{~g} / \mathrm{kg}$ DM of lignosulfonate (EXL)

\begin{tabular}{|c|c|c|c|c|c|c|c|c|}
\hline \multirow[b]{2}{*}{ In sacco degradability } & \multicolumn{4}{|c|}{ Diet } & \multirow[b]{2}{*}{ SEM } & \multicolumn{3}{|c|}{$\mathrm{P}$ value } \\
\hline & $\mathrm{NEC}$ & $\mathrm{EXC}$ & NEL & EXL & & $\mathrm{E}$ & $\mathrm{L}$ & I \\
\hline \multicolumn{9}{|l|}{ Dry matter } \\
\hline Fraction A & 0.31 & 0.34 & 0.28 & 0.36 & 0.01 & 0.001 & 0.63 & 0.09 \\
\hline Fraction B & 0.66 & 0.63 & 0.69 & 0.61 & 0.02 & 0.01 & 0.64 & 0.14 \\
\hline Fraction $\mathrm{C}$ & 0.10 & 0.09 & 0.08 & 0.08 & 0.01 & 0.72 & 0.20 & 0.75 \\
\hline ED & 0.64 & 0.67 & 0.63 & 0.65 & 0.01 & 0.05 & 0.20 & 0.80 \\
\hline \multicolumn{9}{|l|}{ Nitrogen } \\
\hline Fraction A & $0.24 \mathrm{a}$ & $0.24 \mathrm{a}$ & $0.27 \mathrm{a}$ & $0.18 b$ & 0.01 & 0.01 & 0.29 & 0.02 \\
\hline Fraction $\mathrm{B}$ & 0.75 & 0.76 & 0.72 & 0.80 & 0.02 & 0.05 & 0.86 & 0.08 \\
\hline Fraction $\mathrm{C}$ & 0.09 & 0.07 & 0.07 & 0.11 & 0.02 & 0.46 & 0.72 & 0.13 \\
\hline ED & 0.64 & 0.59 & 0.59 & 0.64 & 0.04 & 0.94 & 0.99 & 0.31 \\
\hline
\end{tabular}

a,b Means within rows and lignosulfonate treatment with different letters differ $(\mathrm{P}<0.05)$. All trends (i.e., $\mathrm{P} \leq 0.10)$ referred to in the text.

$\mathrm{SEM}=$ standard error of the mean; fraction $\mathrm{A}=$ rapidly degradable (soluble) fraction; fraction $\mathrm{B}=$ potentially degradable fraction; fraction $\mathrm{C}=$ fractional rate of degradation $\left(\mathrm{h}^{-1}\right)$; $\mathrm{ED}=$ effective degradability at $8 \%$ outflow rate per hour; $\mathrm{E}=$ extrusion; $\mathrm{L}=$ lignosulfonate; $\mathrm{I}=$ interaction. 
$50 \mathrm{~g} / \mathrm{kg}$ DM lignosulfonate and heat at $100{ }^{\circ} \mathrm{C}$ for 60 to 120 min (McAllister et al., 1993) effectively reduced degradation of DM and $\mathrm{CP}$ in the rumen. Rumen protection of CP usually parallels fat, as a protein-rich matrix surrounds the fat droplets of oilseeds (Khorasani et al., 1992). This led us to hypothesize that protection of protein against ruminal degradability with lignosulfonate treatment could overcome the negative effects of a greater release of oil with extrusion on ruminal digestion. Protection of protein against ruminal degradability on the diet of extruded canola seeds treated with $50 \mathrm{~g} / \mathrm{kg} \mathrm{DM}$ of lignosulfonate is corroborated by extruded canola seeds treated with lignosulfonate that resulted in the lowest fraction of $\mathrm{N}$ solubilized at initiation of ruminal incubation. As a result, $\mathrm{N}$ duodenal flow was higher for cows fed extruded versus non-extruded canola seeds without lignosulfonate. This is in agreement with the greater $\mathrm{N}$ flow in the duodenum observed for cows fed diets with protein of lower ruminal degradability (Zerbini et al., 1988).

Daily intake and total omasal flow of DM averaged, respectively, $14.5 \mathrm{~kg}$ and $8.96 \mathrm{~kg}$ and they were similar between treatments (Table 3 ). There was a significant interaction between extrusion and lignosulfonate and there was a trend $(\mathrm{P}=0.06)$, respectively, for ruminal digestibility of DM and intestinal digestibility of DM, expressed as a percentage of DM intake. Cows fed extruded canola untreated with lignosulfonate had the lowest DM digestibility in the rumen and the highest DM intestinal digestibility, expressed as a percentage of intake.
Digestibility in the intestine, expressed as a percentage of DM omasal flow, tended $(P=0.05)$ to decrease with lignosulfonate treatment.

The lack of an extrusion effect on feed intake agrees with Bayourthe et al. (2000) for cows fed extruded versus whole canola seeds. Similarly, lignosulfonate treatment of soybean meal had no effect on dry matter intake of cows (Windshitl \& Stern, 1988; Mansfield \& Stern, 1994; Wright et al., 2005).

The lignosulfonate treatment could contribute to decreasing the amount or rate of release of fat in the rumen, which will overcome the negative effect of extrusion on ruminal digestibility and result in similar ruminal and total tract apparent digestibility of $\mathrm{OM}$ for cows fed non-extruded canola seeds treated or not with lignosulfonate versus extruded canola seeds treated with lignosulfonate. However, extrusion of rapeseeds fed at $145 \mathrm{~g} / \mathrm{kg}$ DM (Ferlay et al., 1992) and lignosulfonate treatment of soybean meal and soybean hulls (Mansfield \& Stern, 1994) had no effect on ruminal digestibility, duodenal flow, and total tract apparent digestibility of $\mathrm{OM}$. The conditions of treatment may be responsible for discrepancies between experiments. For example, the effect of extrusion on release of oil in the rumen differs according to the temperature used for treating as shown for soybeans (Chouinard et al., 1997a; Petit et al., 1999). The lack of a lignosulfonate effect on intestinal digestibility of OM agrees with results of Windshitl \& Stern (1988) for cows fed soybean meal.

Table 3 - Intake, omasal flows, ruminal, intestinal and total tract apparent digestibility (TTAD) in Holstein cows fed non-extruded untreated canola seeds (NEC), extruded untreated canola seeds (EXC), non-extruded canola seeds treated with $50 \mathrm{~g} / \mathrm{kg} \mathrm{DM}$ of lignosulfonate (NEL) or extruded canola seeds treated with $50 \mathrm{~g} / \mathrm{kg}$ DM of lignosulfonate (EXL)

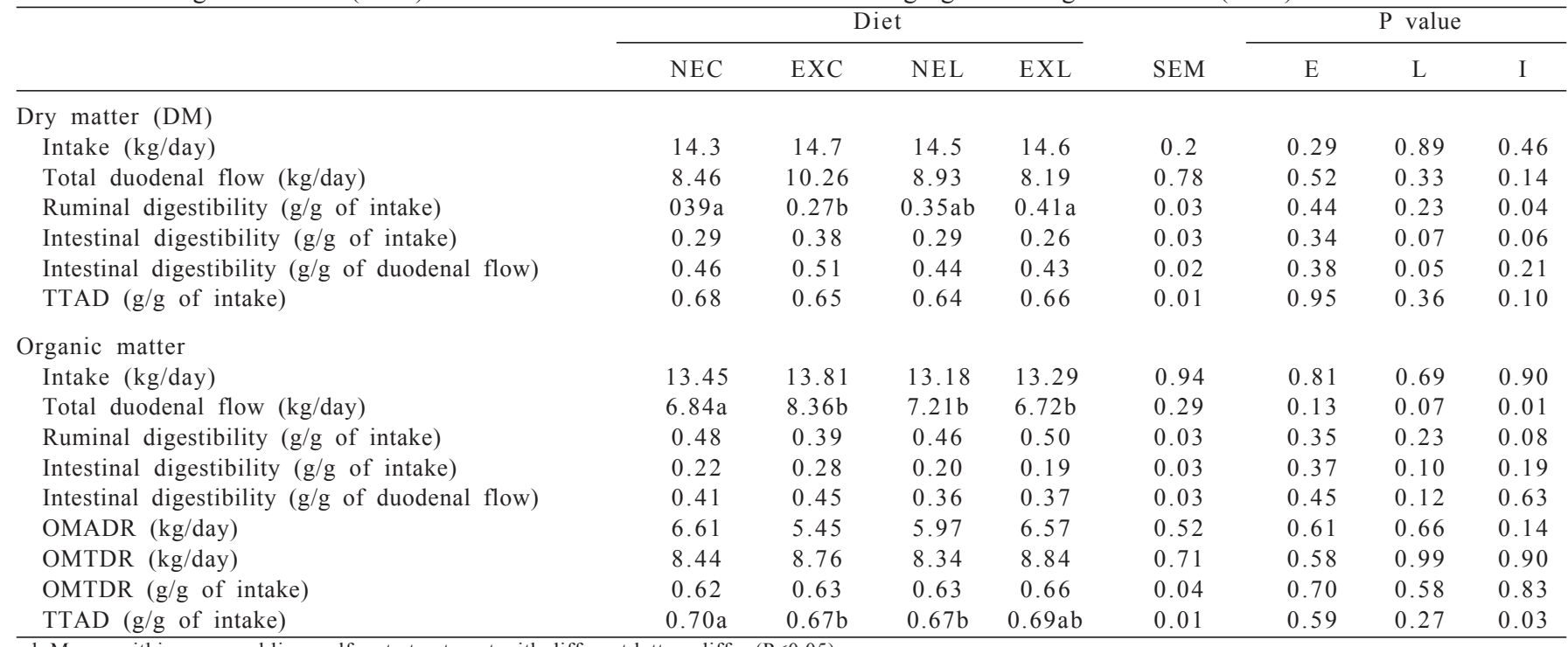

a,b Means within rows and lignosulfonate treatment with different letters differ $(\mathrm{P}<0.05)$. in the rumen (OMADR + microbial OM flow), assuming the ash content of microbial DM was $0.1 ; \mathrm{E}=$ extrusion; $\mathrm{L}=$ lignosulfonate; $\mathrm{I}=$ interaction. 
The total tract apparent digestibility was similar between treatments. Organic matter intake was similar between treatments (Table 3 ). There was a significant interaction between extrusion and lignosulfonate for total OM omasal flow, and cows fed extruded canola untreated with lignosulfonate had the highest flow. Ruminal digestibility of organic matter, expressed as a percentage of organic matter intake, tended $(P=0.08)$ to be lower for cows fed extruded canola untreated with lignosulfonate as shown by the trend for the interaction between extrusion and lignosulfonate. Treating canola with lignosulfonate tended $(\mathrm{P}=0.10)$ to decrease $\mathrm{OM}$ intestinal digestibility, expressed as a percentage of OM intake.

Organic matter intestinal digestibility, expressed as a percentage of omasal flow, OM apparently digested in the rumen, expressed in kilogram per day, and OM truly digested in the rumen, expressed in kilogram per day and as a percentage of organic matter intake, were similar between diets. Total tract apparent digestibility of OM, expressed as a percentage of intake, decreased with extrusion in the absence of lignosulfonate, while extrusion had no effect with the lignosulfonate treatment.

Ether extract intake, expressed in kilogram per day, was significantly higher for cows fed extruded canola untreated with lignosulfonate (Table 4). Extrusion and lignosulfonate treatment had no effect on total omasal flow, ruminal, intestinal and total tract apparent digestibility, expressed as a percentage of intake and intestinal digestibility, expressed as a percentage of omasal flow, of ether extract.

Nitrogen intake was similar between treatments (Table 5). The highest omasal $\mathrm{N}$ flow and microbial $\mathrm{N}$ flow, expressed in grams per day, were observed for cows fed extruded canola untreated without lignosulfonate as shown by the significant interaction between extrusion and lignosulfonate. Non-microbial $\mathrm{N}$ flow, expressed in g per day, was similar between diets. Duodenal N flow, expressed as a percentage of intake, tended $(\mathrm{P}=0.05)$ also to reach the highest value for cows fed extruded untreated canola seeds.

There was an interaction between extrusion and lignosulfonate for microbial efficiency, expressed in $\mathrm{g}$ of $\mathrm{N}$ per kg of organic matter apparently or truly digested in the rumen, and the highest values were obtained for cows fed extruded untreated canola seeds. The lowest apparent ruminal and highest intestinal digestibilities, expressed as a percentage of $\mathrm{N}$ intake, were observed for cows fed extruded untreated canola seeds. True ruminal digestibility, intestinal digestibility, expressed as a percentage of omasal flow, and total tract apparent digestibility of $\mathrm{N}$ were similar among treatments.

Microbial $\mathrm{N}$ flow to the duodenum and efficiency of microbial protein synthesis have been shown to decrease when treating soybean meal with lignosulfonate (Windshitl \& Stern, 1988). In the present experiment, treating extruded canola seeds with lignosulfonate may have protected seeds against degradability and/or fat release in the rumen as discussed previously, while extruded canola seeds with no formaldehyde had no protection, which led to higher microbial $\mathrm{N}$ and total $\mathrm{N}$ flow to the duodenum and lower $\mathrm{N}$ apparent ruminal digestibility. Increased efficiency of microbial protein synthesis also was found with extruded versus non-extruded canola seeds untreated with formaldehyde. According to Murphy et al. (1987), increased efficiency of microbial protein synthesis is a result of fat supplementation of the diet and results of the present experiment suggest that fat from extruded versus nonextruded canola seeds untreated with formaldehyde was more available in the rumen. The higher $\mathrm{N}$ duodenal flow with extruded versus non-extruded canola seeds untreated with formaldehyde was a result of higher microbial $\mathrm{N}$ flow in the duodenum as there was no difference in non-microbial $\mathrm{N}$ flow in the duodenal between diets, which resulted in improved microbial protein synthesis.

Table 4 - Intake, omasal flows, ruminal, intestinal and total tract apparent digestibility (TTAD) in Holstein cows fed non-extruded untreated canola seeds (NEC), extruded untreated canola seeds (EXC), non-extruded canola seeds treated with $50 \mathrm{~g} / \mathrm{kg}$ DM of lignosulfonate (NEL) or extruded canola seeds treated with $50 \mathrm{~g} / \mathrm{kg} \mathrm{DM}$ of lignosulfonate (EXL)

\begin{tabular}{|c|c|c|c|c|c|c|c|c|}
\hline & \multicolumn{4}{|c|}{ Diet } & \multirow[b]{2}{*}{ SEM } & \multicolumn{3}{|c|}{$\mathrm{P}$ value } \\
\hline & NEC & EXC & NEL & EXL & & $\mathrm{E}$ & $\mathrm{L}$ & I \\
\hline \multicolumn{9}{|l|}{ Ether extract } \\
\hline Total duodenal flow (kg/day) & 0.23 & 0.32 & 0.24 & 0.22 & 0.07 & 0.67 & 0.56 & 0.48 \\
\hline Ruminal digestibility ( $\mathrm{g} / \mathrm{g}$ of intake) & 0.77 & 0.74 & 0.78 & 0.80 & 0.05 & 0.89 & 0.58 & 0.68 \\
\hline Intestinal digestibility ( $\mathrm{g} / \mathrm{g}$ of intake) & 0.13 & 0.16 & 0.10 & 0.11 & 0.04 & 0.63 & 0.40 & 0.94 \\
\hline
\end{tabular}

a,b Means within rows and lignosulfonate treatment with different letters differ $(\mathrm{P}<0.05)$.

$\mathrm{SEM}=$ standard error of the mean; $\mathrm{E}=$ extrusion; $\mathrm{L}=$ lignosulfonate; $\mathrm{I}=$ interaction 
Table 5 - Nitrogen intake, omasal $\mathrm{N}$, microbial $\mathrm{N}$ and non-microbial $\mathrm{N}$ flow $(\mathrm{g} / \mathrm{d})$, and $\mathrm{N}$ digestibility in Holstein cows fed non-extruded untreated canola seeds (NEC), extruded untreated canola seeds (EXC), non-extruded canola seeds treated with $50 \mathrm{~g} / \mathrm{kg}$ DM of lignosulfonate (NEL) or extruded canola seeds treated with $50 \mathrm{~g} / \mathrm{kg}$ DM of lignosulfonate (EXL)

\begin{tabular}{|c|c|c|c|c|c|c|c|c|}
\hline & \multicolumn{4}{|c|}{ Diet } & \multirow[b]{2}{*}{ SEM } & \multicolumn{3}{|c|}{$\mathrm{P}$ value } \\
\hline & NEC & $\mathrm{EXC}$ & NEL & EXL & & $\mathrm{E}$ & $\mathrm{L}$ & I \\
\hline Nitrogen intake (g/day) & 434 & 437 & 416 & 420 & 32 & 0.92 & 0.60 & 0.99 \\
\hline Non-microbial $\mathrm{N}$ flow (g/day) & 134 & 107 & 126 & 117 & 33 & 0.60 & 0.97 & 0.80 \\
\hline Microbial $\mathrm{N}$ flow (g/day) & $157 \mathrm{~b}$ & $263 \mathrm{a}$ & $191 b$ & $176 \mathrm{~b}$ & 23 & 0.09 & 0.28 & 0.04 \\
\hline $\mathrm{N}$ flow/ $\mathrm{N}$ intake & 0.68 & 0.85 & 0.75 & 0.70 & 0.05 & 0.28 & 0.44 & 0.05 \\
\hline \multicolumn{9}{|l|}{$\mathrm{N}$ digestibility } \\
\hline Apparent ruminal (g/100 $\mathrm{g}$ of intake) & $32.0 \mathrm{a}$ & $15.0 \mathrm{~b}$ & $25.0 \mathrm{a}$ & $30.0 \mathrm{a}$ & 0.04 & 0.17 & 0.32 & 0.02 \\
\hline True ruminal ${ }^{1}$ & 0.69 & 0.76 & 0.70 & 0.72 & 0.07 & 0.51 & 0.88 & 0.72 \\
\hline Intestinal digestibility $(\mathrm{g} / 100 \mathrm{~g}$ of intake) & $43.0 \mathrm{~b}$ & $58.0 \mathrm{a}$ & $47.0 \mathrm{~b}$ & $43.0 \mathrm{~b}$ & 0.04 & 0.18 & 0.17 & 0.04 \\
\hline
\end{tabular}

a,b Means within rows and lignosulfonate treatment with different letters differ $(\mathrm{P}<0.05)$.

$\mathrm{SEM}=$ standard error of the mean; OMADR $=$ organic matter apparently digested in the rumen (OM intake - OM duodenal flow); OMTDR $=$ organic matter truly digested in the rumen (OMADR + microbial OM flow), assuming the ash content of microbial DM as $0.1 ; \mathrm{E}=\mathrm{extrusion;} \mathrm{L}=1$ ignosulfonate; $\mathrm{I}=$ interaction; TTAD = total tract apparent digestibility.

1 True ruminal $\mathrm{N}$ digestibility: $1-[(\mathrm{N}$ flow - microbial $\mathrm{N}) / \mathrm{N}$ intake $]$

There was a shift in digestibility of $\mathrm{N}$ from the rumen to the small intestine with extruded versus non-extruded canola seeds untreated with formaldehyde, which may increase the amount of rumen bypass protein available to the cows. This agrees with results of Solanas et al. (2005), who reported that residues from ruminal incubation of extruded versus non-extruded feeds such as soybeans and lupins had higher intestinal $\mathrm{N}$ digestibility. However, there was no difference in intestinal $\mathrm{N}$ digestibility between extruded versus non-extruded canola seeds treated with the formaldehyde treatment. This disagrees with von Keyserlingk et al. (2000), who observed an increase in intestinal CP disappearance of lignosulfonate-treated canola screenings when compared with untreated canola screenings, although the total tract apparent digestibility of CP was not affected by the $50 \mathrm{~g} / \mathrm{kg}$ DM lignosulfonate treatment, as observed in the present experiment.

The lack of an extrusion effect on ruminal digestibility of ether extract is in agreement with results of Bauchart et al. (1990), who observed similar duodenal flows of linoleic acid at the duodenum between diets containing raw versus extruded rapeseeds. Moreover, Gonthier et al. (2004) found no effect of extrusion of flaxseed on ruminal digestibility, post-ruminal digestibility and total tract apparent digestibility of fatty acids. Similarly, Scott et al. (1991) found no effect of extrusion of soybeans on the total tract apparent digestibility of fatty acids.

There was no interaction between extrusion and lignosulfonate and between treatment and sampling time for any parameters of ruminal fermentation (Table 6). Ruminal $\mathrm{pH}, \log \mathrm{H}$, concentrations of ammonia, total volatile fatty acids (VFA), and molar proportions of VFA were similar between treatments. Treatment with lignosulfonate tended $(\mathrm{P}=0.09)$ to decrease the acetate-to-propionate ratio in the rumen.

The lack of an extrusion effect on ruminal $\mathrm{pH}$, total VFA, and molar proportions of individual VFA disagrees with results of Khorasani \& Kennelly (1998), who reported trends for higher ruminal $\mathrm{pH}$ and lower total VFA concentrations and molar percentages of propionate with an increased amount of canola seeds from 0 to $145 \mathrm{~g} / \mathrm{kg} \mathrm{DM}$ in the diet of dairy cows.

Changes in the proportions of propionate and acetate in the rumen with canola seed supplementation (Leupp et al., 2006) have been attributed to a decrease in ruminal fiber digestion. However, although there was a trend towards lower acetate-to-propionate ratio with the lignosulfonate treatment in the present experiment, there was no difference in the total tract apparent digestibility of fiber between diets (Neves et al., 2009). Lignosulfonate has been shown to decrease protein degradability in the rumen (Windschitl \& Stern, 1988), which decreases ammonia $\mathrm{N}$ in the rumen (Zerbini et al., 1988). However, in the present experiment, effective degradability of $\mathrm{N}$ was not affected by lignosulfonate or extrusion, which may explain that ammonia $\mathrm{N}$ concentration in the rumen was similar between treatments. 
Table 6 - Ruminal pH and concentrations of ammonia and total volatile fatty acids (VFAs) and molar proportions of individual VFA of Holstein cows fed non-extruded untreated canola seeds (NEC), extruded untreated canola seeds (EXC), non-extruded canola seeds treated with $50 \mathrm{~g} / \mathrm{kg}$ DM of lignosulfonate (NEL) or extruded canola seeds treated with $50 \mathrm{~g} / \mathrm{kg}$ DM of lignosulfonate (EXL)

\begin{tabular}{|c|c|c|c|c|c|c|c|c|}
\hline & \multicolumn{4}{|c|}{ Diet } & \multirow[b]{2}{*}{ SEM } & \multicolumn{3}{|c|}{$\mathrm{P}$ value } \\
\hline & NEC & EXC & NEL & EXL & & $\mathrm{E}$ & $\mathrm{L}$ & I \\
\hline \multicolumn{9}{|l|}{ Rumen variables } \\
\hline Log $\mathrm{pH}$ & 0.80 & 0.80 & 0.79 & 0.80 & 0.01 & 0.24 & 0.17 & 0.61 \\
\hline Ammonia $(\mathrm{mg} / \mathrm{L})$ & 156.6 & 161.6 & 151.1 & 148.7 & 6.5 & 0.85 & 0.21 & 0.60 \\
\hline Total VFA $(\mathrm{mmol} / \mathrm{L})$ & 89.5 & 92.3 & 96.9 & 101.8 & 8.5 & 0.67 & 0.36 & 0.91 \\
\hline \multicolumn{9}{|l|}{ VFAs $(\mathrm{mmol} / \mathrm{mol})$} \\
\hline Propionic acid & 24.42 & 22.98 & 27.88 & 29.83 & 3.64 & 0.94 & 0.18 & 0.65 \\
\hline iso-Butyric acid & 0.26 & 0.25 & 0.24 & 0.44 & 0.11 & 0.39 & 0.45 & 0.35 \\
\hline$n$-Butyric acid & 9.97 & 8.52 & 10.45 & 11.68 & 1.88 & 0.95 & 0.35 & 0.49 \\
\hline iso-Valeric acid & 2.75 & 2.75 & 2.14 & 2.88 & 0.31 & 0.26 & 0.46 & 0.26 \\
\hline$n$-Valeric acid & 0.78 & 0.96 & 1.13 & 1.14 & 0.29 & 0.74 & 0.37 & 0.78 \\
\hline Acetate:propionate & 2.51 & 2.40 & 2.30 & 2.04 & 0.16 & 0.25 & 0.09 & 0.65 \\
\hline
\end{tabular}

$\mathrm{SEM}=$ standard error of the mean; $\mathrm{E}=$ extrusion; $\mathrm{L}=$ lignosulfonate; $\mathrm{I}=$ interaction; $\mathrm{VAF}=$ volatile fatty acid.

\section{Conclusions}

Fat supplementation from canola seeds at $140 \mathrm{~g} / \mathrm{kg}$ DM in the form of extruded vs non-extruded and untreated $v s$ treated with $50 \mathrm{~g} / \mathrm{kg}$ DM lignosulfonate had no effect on the flows of organic matter and ether extract to the duodenum. Moreover, results suggest that extruded canola seed untreated with formaldehyde may stimulate efficiency of microbial protein synthesis and is an effective means of increasimg the availability of protein in the small intestine without affecting the total tract apparent digestibility of protein.

\section{Acknowledgements}

The project was supported by Fundação Araucária, Curitiba, PR and CNPq, Brasilia, DF, under protocol no. 10913/2006,PRONEX/2006.

\section{References}

ABU-GHAZALEH, A.A.; SCHINGOETHE, D.J.; HIPPEN, A.R. et al. Feeding fish meal and extruded soybeans enhances the conjugated linoleic acid (CLA) content of milk. Journal of Dairy Science, v. 85, p.624-631, 2002a.

ABU-GHAZALEH, A.A.; SCHINGOETHE, D.J.; HIPPEN, A.R. et al. Fatty acid profiles of milk and rumen digesta from cows fed fish oil, extruded soybeans or their blend. Journal of Dairy Science, v.85, p.2266-2276, 2002 b.

ASSOCIATION OF OFFICIAL AGRICULTURAL CHEMISTS AOAC. Official methods of analysis. 15.ed. AOAC, Washington, D.C.: AOAC, 1990. 648p.

BAUCHART, D.; LEGAY-CARMIER, F.; DOREAU, M. Relationship between intake and duodenal flows of linoleic acid in dairy cows fed lipid-supplemented diets. Reproduction Nutrition Development, v.30, p.188-188s, 1990 (abstracts). DOI: http://dx.doi.org/10.1051/rnd:19900825
BAYOURTHE, C.; ENJALBERT, F.; MONCOULON, R. Effects of different forms of canola oil fatty acids plus canola meal on milk composition and physical properties of butter. Journal of Dairy Science, v.83, p.690-696, 2000.

CECAVA, M.J.; MERCHEN, N.R.; GAY, L.C. et al. Composition of ruminal bacteria harvested from steers as influenced by dietary energy level, feed frequency, and isolation techniques. Journal of Dairy Science, v.73, p.2480-2490, 1990.

CHOUINARD, P.Y.; LÉVESQUE, J.; GIRARD, V. et al. Dietary soybeans extruded at different temperatures: milk composition and in situ fatty acid reactions. Journal of Dairy Science, v.80, p.2913-2924, 1997a.

CHOUINARD, P.Y.; GIRARD, V.; BRISSON, G.J. Performance and profiles of milk fatty acids of cows fed full fat, heat-treated soybeans using various processing methods. Journal of Dairy Science, v.80, p.334-342, 1997 b.

COCHRAN, R.C.; ADAMS, D.C.; WALLACE, J.D. et al. Predicting digestibility of different diets with internal markers: evaluation of four potential markers. Journal of Dairy Science, v. 63 , p.1476-1483, 1986.

DHANOA, M.S.; FRANCE, J.; LOPEZ, S. et al. Correcting the calculation of extent of degradation to account for particulate matter loss at zero time when applying the polyester bag method. Journal of Animal Science, v.77, p.3385-3391, 1999.

DANN, H.M.; CARTER, M.P.; COTANCH, K.W. Effect of partial replacement of forage neutral detergent fiber with by-product neutral detergent fiber in close-up diets on periparturient performance of dairy cows. Journal of Dairy Science, v.90, p.1789-1801, 2007.

DEACON, M.A.; DE BOER, G.; KENNELLY, J.J. Influence of jetSploding and extrusion on ruminal and intestinal disappearance of canola and soybeans. Journal of Dairy Science, v.71, p.745-753, 1988 .

ELLIS, W.C.; BAILEY, E.M.; TAYLOL, C.A. A silicone esophageal cannula; its surgical installation and use in research with grazing cattle, sheep or goats. Journal of Animal Science, v.59, p.204-209, 1984.

FERLAY, A.; LEGAY, F.; BAUCHART, D. et al. Effect of a supply of raw or extruded rapeseeds on digestion in dairy cows. Journal of Dairy Science, v.70, p.915-923, 1992.

GONTHIER, C.; MUSTAFA, A.F.; BERTHIAUME, R. et al. Feeding micronized and extruded flaxseed to dairy cows: effects on digestion and ruminal biohydrogenation of long-chain fatty acids. Can. Journal of Animal Science, v.84, p.705-711, 2004. 
GRIINARI, J.M.; BAUMAN, D.E. Biosynthesis of conjugated linoleic acid and its incorporation into meat and milk in ruminants. In: YURAWECZ, M.P.; MOSSABA, M.M.; KRAMER, J.K.G. et al. (Eds.) Advances in conjugated linoleic acid research. Champaign: AOCS Press, 1999. v.1, p.180-200.

HUHTANEN, P.; KAUSTELL, K.; JAAKKOLA, S. The use of internal markers to predict total digestibility and duodenal flow of nutrients in cattle given six different diets. Animal Feed Science and Technology, v.48, p.211-227, 1994.

HUHTANEN, P.; BROTZ, P.G.; SATTER, L.D. Omasal sampling technique for assessing fermentative digestion in the forestomach of dairy cows. Journal of Animal Science, v.75, p.1380-1392, 1997.

KENNELLY, J.J. The fatty acid composition of milk fat as influenced by feeding oilseeds. Animal Feed Science and Technology, v.60, p.137-152, 1996.

KHORASANI, G.R.; DE BOER, G.; ROBINSON, P.H. et al. Effect of canola fat on ruminal and total tract digestion, plasma hormones, and metabolites in lactating dairy cows. Journal of Dairy Science, v.75, p.492-501, 1992.

KHORASANI, G.R.; KENNELLY, J.J. Effect of added dietary fat on performance, rumen characteristics, and plasma metabolites of midlactation dairy cows. Journal of Dairy Science, v.81, p.2459-2468, 1998.

LEUPP, J.L.; LARDY, G.P.; SOTO-NAVARRO, S.A. et al. Effects of canola seed supplementation on intake, digestion, duodenal protein supply, and microbial efficiency in steers fed foragebased diets. Journal of Animal Science, v.84, p.499-507, 2006.

MANSFIELD, H.R.; STERN, M.D. Effects of soybean hulls and lignosulfonate-treated soybean meal on ruminal fermentation in lactating dairy cows. Journal of Dairy Science, v.77, p.1070-1083, 1994.

MCALLISTER, T.A.; CHENG, K.J.; BEAUCHEMIN, K.A. et al. Use of lignosulfonate to decrease the rumen degradability of canola meal protein. Canadian Journal of Animal Science, v.73, p.211-215, 1993.

MCDONALD, I. A revised model for the estimation of protein degradability in the rumen. Journal of Agricultural Science, v.96, p.251-252, 1981

MOHAMED, O.E.; SATTER, L.D.; GRUMMER, R.R. et al. Influence of dietary cottonseed and soybean on milk production and composition. Journal of Dairy Science, v.71, p.2677-2688, 1988 .

MURPHY, M.; UDEN, P.; PALMQUIST, D.L. et al. Rumen and total diet digestibilities in lactating cows fed diets containing full-fat rapeseed. Journal of Dairy Science, v.70, p.1572-1582, 1987.

MUSTAFA, A.F.; MCKINNON, J.J.; CHRISTENSEN, D.A. et al. Effects of micronization of flaxseed on nutrient disappearance in the gastrointestinal tract of steers. Animal Feed Science and Technology, v.95, p.123-132, 2002.

NATIONAL RESEARCH COUNCIL - NRC. Nutrient requirements of dairy cattle. 7.rev.ed. Washington, D.C.: National Acaddmy Press, 2001. 381p.

NEVES, C.A.; SANTOS, G.T.D.; MATSUSHITA, M. et al. Intake, digestibility, milk production, and milk composition of Holstein cows fed extruded soybeans treated with lignosulfonate. Animal Feed Science and Technology, v.134, p.32-44, 2007.

NEVES, C.A.; DOS SANTOS, W.B.R.; SANTOS, G.T.D. et al. Production performance and milk composition of dairy cows fed extruded canola seeds treated with or without lignosulfonate Animal Feed Science and Technology, v.154, p.83-92, 2009.

PENA, F.; TAGARI, H.; SATTER, L.D. The effect of heat treatment of whole cottonseed on site and extent of protein digestion in dairy cows. Journal of Dairy Science, v.62, p.1423-1433, 1986.

PETERSON, D.G.; KELSEY, J.A.; BAUMAN, D.E. Analysis of variation in cis-9, trans-11 conjugated linoleic acid (CLA) in milk fat of dairy cows. Journal of Dairy Science, v.85, p.2164-2172, 2002

PETIT, H.V.; TREMBlay, G.F.; TURCOTTE, M. et al. Degradability and digestibility of full-fat soybeans treated with different sugar and heat combinations. Can. Journal of Animal Science, v.79, p.213-220, 1999.

PETIT, H.V.; RIOUX, R.; D'OLIVEIRA, P.S. et al. Performance of growing lambs fed grass silage with raw or extruded soybean or canola seeds. Canadian Journal of Animal Science, v.77, p.455-463, 1997.

PONCET, C.; RÉMOND, D. Rumen digestion and intestinal nutrient flows in sheep consuming pea seeds: the effect of extrusion and of chestnut tannin addition. Animal Research, v.51, p.201-206, 2002.

REDDY, P.V.; MORRILL, J.L.; NAGARAJA, T.G. Release of free fatty acids from raw or processed soybeans and subsequent effects on fiber digestibilities. Journal of Dairy Science, v.77, p.3410-3416, 1994.

SCOTT, T.A.; COMBS, D.K.; GRUMMER, R.R. Effects of roasting, extrusion, and particle size on the feeding value of soybeans for dairy cows. Journal of Dairy Science, v.74, p.2555-2562, 1991.

SOlAnAS, E.; CASTRILlO, C.; BALCELlS, J. et al. In situ ruminal degradability and intestinal digestion of raw and extruded legume seeds and soyba mean meal protein. Journal of Animal Physiology and Animal Nutrition, v.89, p.166-171, 2005.

USHIDA, K.; LALLALAS, B.; JOUANY, J.P. Determination of assay parameters for RNA analysis in bacterial and duodenal samples by spectrophotometry. Influence of sample treatment and preservation. Reproduction Nutrition Development, v. 25 , p. $1037-1046 ., 1985$.

VAN SOEST, P.J.; ROBERTSON, J.B.; LEWIS, B.A. Methods for dietary fiber, neutral detergent fiber, and nonstarch polysaccharides in relation to animal nutrition. Journal of Dairy Science, v.74, p.3583-3597, 1991.

VON KEYSERLINGK, M.A.G.; WEURDING, E.; SWIFT, M.L. Effect of adding lignosulfonate and heat to canola screenings on ruminal and intestinal disappearance of dry matter and crude protein. Journal Animal Science, v. 80, p.215-219, 2000.

WINDSCHITL, P.M.; STERN, M.D. Evaluation of calcium lignosulfonate-treated soybean meal as a source of rumenprotected protein for dairy cattle. Journal of Dairy Science, v.71, p.3310-3325, 1988.

WRIGHT, C.F.; VON KEYSERLINGK, M.A.G.; SWIFT, M.L. et al Heat- and lignosulfonate-treated canola meal as a source of ruminal undegradable protein for lactating dairy cows. Journal of Dairy Science, v.88, p.238-243, 2005.

ZERBINI, E.; POLAN, C.E.; HERBEIN, J.H. Effect of dietary soybean meal and fish meal on protein digesta flow in Holstein cows during early and midlactation. Journal of Dairy Science, v.71, p.1248-1258, 1988 . 